\title{
Studies on the antimicrobial effect of corn steep liquor on some diarrhoea causing organisms
}

\author{
Abdus-Salaam, R. B. ${ }^{*}$, Adepoju, P. A., Olaleye O. N. and Adeoye, I. A. \\ Department of Food Technology, Lagos State Polytechnic, Ikorodu, Lagos, Nigeria.
}

Accepted 18 December, 2013

\begin{abstract}
The antimicrobial effect of Corn Steep Liquor (CSL) was investigated over a five day period. The $\mathrm{pH}$ and titrable acidity of the liquor were determined, while the antimicrobial effect on some diarrhoea causing organisms such as Escherichia coli, Salmonella enteriditis, Staphylococcus aureus and Vibrio parahaemolyticus was also determined. Using well diffusion method, $0.1 \mathrm{ml}(100 \mu \mathrm{l})$ of the liquor effectively inhibited the growth of the test organisms with zones of inhibition ranging from $4.00 \pm 0.28$ to $20.20 \pm 0.14 \mathrm{~mm}$. The zones of inhibition increased with increasing number of days of fermentation of the filtrate on which is the CSL. However, there was no significant difference $(P>0.05)$ in the antimicrobial properties of the liquor on day 3 and 4 for $S$. enteriditis, $S$. aureus and $V$. parahaemolyticus. The zone of inhibition on day 5 was significantly different $(P<0.05)$ from all other days except in S. enteriditis whose zone of inhibition was not significantly different from day 4 and 5 . The degree of inhibition was highest in $E$. coli $(20.20 \pm 0.14 \mathrm{~mm})$, followed by $V$. paraheamolyticus $(18.50 \pm$ $2.12 \mathrm{~mm})$; while $S$. enteriditis showed the minimum degree of inhibition to the CSL $(13.20 \pm 0.28 \mathrm{~mm}$. The total microbial count and the titrable acidity of the liquor increased with increasing number of days and reached a peak on day $4(355.60 \pm 21.07 \mathrm{cfu} / \mathrm{ml}$ and $23.25 \pm 2.05 \%$, respectively). The $\mathrm{pH}$ however decreased with number of days. The result suggests that corn steep liquor which is considered a waste inhibits the growth of some diarrhoeic microbes especially by day four of fermentation.
\end{abstract}

Key words: Anti-microbials, diarrhoea, $\mathrm{pH}$, titrable acidity.

\section{INTRODUCTION}

According to the study of Vrese and Marteau (2007), the WHO defines diarrhoea as three or more watery stools on two or more consecutive days. Acute diarrhoea from viral (mostly rotaviruses) or bacterial infection is still a major health problem worldwide and a frequent cause of death, especially in hospitalized children in developing countries. According to the study of Walderman (1998), it is one of the most common diseases that cause infant deaths in developing countries, nevertheless infectious diarrhoea is not only a problem of developing countries because up to $30 \%$ of the population in developed countries are affected by food-borne bacterial diarrhoeas each year. Different factors contribute to the incidence of diarrhoea. One of which is the consumption of foods contaminated by pathogens. These pathogens include $E$. coli, Salmonella species, Shigella spp, S. aureus, Clostridium difficile and Campylobacter jejumi among others (Prescott et al., 2005). It is a common lifethreatening disease which can lead to dehydration, and alters the child's natural balance of water and electrolytes (sodium, potassium, chloride) and can be serious if not treated promptly. Diarrhoea, although self-limiting may sometimes require antibiotic therapy. However, most of the aetiological agents especially bacteria have already developed resistance to most of the commonly employed antibiotics (Ashebir and Ashenati, 1999) and according 


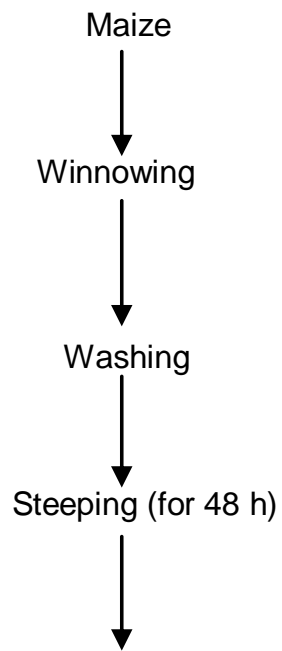

Draining<smiles>CCCC</smiles>

Wet milling<smiles>CCC</smiles>

Wet sieving<smiles>CI</smiles>

Further fermentation/souring (for 5 days)

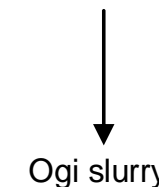

Figure 1. Flow chart for the production of Ogi. Source: Odunfa and Adeleye (1985).

to Chessbrough (1994) and Marteau et al. (2002), some of these antibiotics can also induce diarrhoea known as "antibiotic induced diarrhea". Therefore, there is need to find alternative means of treatment of this disease.

Fermented products are known to posses antimicrobial properties (Marugg, 1991). Ogi is a traditional fermented starch cake processed from maize, sorghum or millet. The most predominant microorganism involved in the fermentation of maize during ogi production is Lactobacillus plantarum while other microorganisms are associated with it. L. plantarum is responsible for the production of lactic acid which is the major component of ogi flavour and taste. Ogi usually has a smooth texture and is boiled into a porridge called pap before consumption. Fermented foods have been known to exhibit health-promoting properties such as control of gastroenteritis in animals and man. This has been demonstrated by locals who drink the raw slurry when there is a case of diarrhoea. Information regarding the probiotic effects of both the traditional ogi slurry (Oyetayo and Osho, 2004; Aderiye et al., 2007) as well as improved ogi for example Dogik (Olukoya et al., 1994) is well documented. However, there is paucity of information regarding the probiotic effect of the CSL which is always considered a waste. This study therefore, investigated the antimicrobial properties of CSL on some diarrhea-causing organisms.

\section{MATERIALS AND METHODS}

Dirt-free sorted maize grains bought from a local market at Yaba in Lagos State, were used. Ogi was produced following the method of Odunfa and Adeleye (1985) (Figure 1). The grains were winnowed and washed with sterile water before soaking for $48 \mathrm{~h}$, after which the steep water was drained and the grains wet milled using a double grinding mill (Asiko Engineering, Nigeria). The wet-milled grains were wet sieved as done locally using a hand sieve. The ogi gruel produced was left to settle into ogi and corn steep liquor (CSL). A quantity of the CSL on the fermenting maize slurry (ogi) was collected daily for 5 days.

\section{Analysis}

\section{Determination of $\mathrm{pH}$ and TTA}

The $\mathrm{pH}$ and total titrable acidity of the CSL were determined according to AOAC (1990). Briefly, $10 \mathrm{ml}$ of the liquor was aseptically taken in sterile tubes for the $\mathrm{pH}$ determination. This was followed by the insertion of $\mathrm{pH}$ electrode of a $\mathrm{pH}$ meter (model Oakton, Japan) that has been standardized at $\mathrm{pH} 4$ and 7 . The titrable acidity was determined by titrating $10 \mathrm{ml}$ of the liquor with $0.1 \mathrm{M} \mathrm{NaOH}$ using 2 drops of methyl orange as indicator.

\section{Total bacteria count}

To determine the total bacteria count, $10 \mathrm{ml}$ of the corn steep liquor was mixed with $90 \mathrm{ml}$ sterile peptone water. Ten fold dilutions were made and aliquots of the appropriate dilutions were plated on Nutrient agar $\left(\mathrm{Lab}^{\mathrm{m}}\right)$ using the pour plate method. The plates were incubated at $25^{\circ} \mathrm{C}$ for 24 to $48 \mathrm{~h}$. Colonies were counted and expressed as colony forming units (cfu) per $\mathrm{ml}$ of the corn steep liquor.

\section{Collection of bacteria cultures}

Broth cultures of Escherichia coli, Salmonella enteriditis, Staphylococcus aureus and Vibrio parahaemolyticus were collected from the Microbiology Department, Nigeria Institute of Medical Research (NIMR), Yaba, Lagos State. The bacteria were inoculated at $37 \pm 2^{\circ} \mathrm{C}$ for $24 \mathrm{~h}$ using appropriate media.

\section{Measurement of antibacterial activities of CSL}

One milliliter $(1 \mathrm{ml})$ of broth culture of each of the test organisms 
Table 1. Diameter $(\mathrm{mm})$ of zones of inhibition of test organisms by CSL.

\begin{tabular}{cccccc}
\hline $\begin{array}{c}\text { Duration } \\
\text { (days) }\end{array}$ & $\begin{array}{c}\text { Escherichia } \\
\text { coli }\end{array}$ & $\begin{array}{c}\text { Staphylococcus } \\
\text { aureus }\end{array}$ & $\begin{array}{c}\text { Salmonella } \\
\text { enteritidis }\end{array}$ & $\begin{array}{c}\text { Vibrio parahaemo- } \\
\text { lyticus }\end{array}$ & $\begin{array}{c}\text { Total bacteria count } \\
\text { (cfu/ml) } \times 10^{3}\end{array}$ \\
\hline Day 1 & $0.00\left( \pm 0.00^{\mathrm{b}}\right.$ & $0.00\left( \pm 0.00^{\mathrm{b}}\right.$ & $0.00\left( \pm 0.00^{\mathrm{b}}\right.$ & $0.00\left( \pm 0.00^{\mathrm{b}}\right.$ & $51.90( \pm 8.76)^{\mathrm{b}}$ \\
Day 2 & $4.00( \pm .28)^{\mathrm{c}}$ & $0.00\left( \pm 0.00^{\mathrm{b}}\right.$ & $0.00\left( \pm 0.00^{\mathrm{b}}\right.$ & $9.20( \pm 1.13)^{\mathrm{c}}$ & $85.50( \pm 20.78)^{\mathrm{b}}$ \\
Day 3 & $10.15( \pm .21)^{\mathrm{d}}$ & $9.85( \pm .63)^{\mathrm{c}}$ & $9.60( \pm .98)^{\mathrm{c}}$ & $12.65( \pm .21)^{\mathrm{d}}$ & $228.15( \pm 28.77)^{\mathrm{d}}$ \\
Day 4 & $14.85( \pm .49)^{\mathrm{e}}$ & $10.30( \pm 1.27)^{\mathrm{c}}$ & $11.10( \pm 1.97)^{\mathrm{ca}}$ & $14.00( \pm 1.41)^{\mathrm{d}}$ & $355.60( \pm 21.07)^{\mathrm{a}}$ \\
Day 5 & $20.20( \pm .14)^{\mathrm{a}}$ & $13.65( \pm .21)^{\mathrm{a}}$ & $13.20( \pm .28)^{\mathrm{a}}$ & $18.50( \pm 2.12)^{\mathrm{a}}$ & $152.95( \pm 38.53)^{\mathrm{c}}$ \\
\hline
\end{tabular}

Values are means of duplicate determination \pm SD. Means in a column with the same alphabets are not significantly different $(P>0.05)$.

Table 2. $\mathrm{pH}$ and titrable acidity during fermentation.

\begin{tabular}{ccc}
\hline Duration (days) & $\mathbf{p H}$ & Titrable acidity (\%) \\
\hline Day 1 & $5.31( \pm .04)^{\mathrm{a}}$ & $0.14( \pm 0.02)^{\mathrm{b}}$ \\
Day 2 & $5.10( \pm .02)^{\mathrm{d}}$ & $0.15( \pm 0.01)^{\mathrm{b}}$ \\
Day 3 & $4.91( \pm .05)^{\mathrm{c}}$ & $0.20( \pm 0.01)^{\mathrm{c}}$ \\
Day 4 & $4.81( \pm .05)^{\mathrm{c}}$ & $0.23( \pm 0.02)^{\mathrm{a}}$ \\
Day 5 & $4.64( \pm .08)^{\mathrm{b}}$ & $0.22( \pm 0.02)^{\mathrm{a}}$ \\
\hline
\end{tabular}

Values are means of duplicate determination. Means having same alphabet along the column are not significantly different $(P>0.05)$.

was plated in each Petri dish and $20 \mathrm{ml}$ of nutrient agar was poured on each plate, carefully swirled for $5 \mathrm{~s}$ and were allowed to set. Thereafter, six wells of $4 \mathrm{~mm}$ diameter were bored in the agar with the aid of a sterile cork borer. $0.1 \mathrm{ml}(100 \mu \mathrm{l})$ of CSL from each day

\section{RESULTS AND DISCUSSION}

From Table 1, the CSL taken on day 2 to 5 showed antibacterial activities against the test organisms, except $S$. aureus and $S$. enteritidis which were not inhibited on day 2. This observation is collaborated by Adebolu et al. (2007). The CSL had the highest inhibitory effect on the growth of $E$. coli and $V$. parahaemolyticus on day 5 with zones of inhibition of $20.20 \mathrm{~mm} \pm 0.14$ and $18.5 \mathrm{~mm} \pm$ 2.12, respectively while the lowest inhibitory effect of the liquor was also on $E$. coli on day 2 with zone of inhibition of $4.0 \mathrm{~mm}$. Its highest activity on day 5 is proportionally related to the increasing acidity of the liquor making it highly inhibitory on the growth of the microbes. Olsen et al. (1995) explained that the antimicrobial effect was due to the combined effect of acids, compounds sensitive to proteolytic enzymes and other compounds with antimicrobial activity with the acid production being the most important factor. In a similar study, Bakre et al. (1998) showed that inoculated enteric pathogens were inhibited in cooked ogi and koko during storage for 24 to $48 \mathrm{~h}$ and noted that none of the bacteria studied was recovered after $48 \mathrm{~h}$ except Shigella spp and ETEC in ogi. Generally, the inhibitory effect of the CSL increases with the length of days of the fermenting maize slurry (ogi).
The zones of inhibition obtained for all samples were significantly different $(P<0.05)$ from day 5 except for $S$. enteritidis. This finding also showed that there was no significant difference $(P>0.05)$ in the anti microbial effect of the CSL on most organisms on day 3 and 4 , except with E. coli.

The result also indicates that the total bacteria count increased from day 1 to 4 ranging from $51.90 \times 103$ $\mathrm{cfu} / \mathrm{ml}$ to $355.60 \mathrm{cfu} / \mathrm{ml} \times 103$. The total bacteria count recorded in this study on day 3 fermentation is higher than the value obtained by George-Okafor and Anosile (2011). Table 2 shows the result of the $\mathrm{pH}$ and total titrable acidity (TTA). The total titrable acidity measured as percentage lactic acid ranged from 0.14 to $0.23 \%$. This shows that lactic acid was actually present in the liquors. The low $\mathrm{pH}$ of the liquor which also ranged from 4.64 to 5.31 could be partly responsible for the inhibition because most bacteria cannot grow at low $\mathrm{pH}$ except a few such as the lactic acid bacteria (Lindgren and Dobrogosz, 1990; Savadogo et al., 2006). The pH of the CSL decreased from 5.31 on day 1 to 4.64 on day 5 while the tirable acidity increased from 0.14 on day 1 to 0.23 on day 4 and thereafter dropped. Omemu et al. (2007) reported similar trend in the TTA of ogi samples. The $\mathrm{pH}$ of the liquor on day 3 and 4 was not significantly different from one another but significant difference exists between these two days and the other days. Although, significant difference exists between the total bacterial count in the liquor on days 4 and 5 , this was not followed by a corresponding significant difference $(P<0.05)$ in the titrable acidity for the same period. The increasing acidity which was highest on day 4 gave a corresponding highest total bacterial count $(355.60 \pm 21.07 \mathrm{cfu} / \mathrm{ml})$. However, the total bacterial count dropped on the 5th day while at the same time the zones of inhibition increased. This may be due to a likely onset of the production of other antimicrobial metabolites by the $L A B$ which had significant effect on the total bacterial count as well as increasing the zones of inhibition.

The CSL is reported to contain lactic acid bacteria $(\mathrm{LAB})$ and some other bioactive components which possess inhibitory effect on these organisms. One of these bioactive components could be bacteriocins which are proteinaceous antimicrobial components that are inhibitory towards sensitive organisms (Ogunbanwo et al., 
2003) and which act by destroying the bacterial membrane (Savadago et al., 2006). This could be a possibility because Lactobacilli have been reported by Lindgren and Dobrogosz (1990) and Brink et al. (1994) to produce various compounds such as organic acids, diacetyl, hydrogen peroxide and bacteriocins during lactic acid fermentation. LAB have long been known to produce bacteriocins (Maruggi, 1991), to a range of organisms including Gram-negative and Gram-positive. GeorgeOkafor and Anosike (2011) isolated three LAB from corn waste liquor and showed their antimicrobial effect on some test organisms. Caplice and Fitzerald (1999) attributed the anti microbial effect of LAB to lactic acid and organic acids produced causing the $\mathrm{pH}$ of the growth environment to decrease. Vresse and Marteau (2007) suggested mechanisms for the effects/actions of the bacteriocins on the intestinal microflora which include lowering of the intestinal $\mathrm{pH}$, production of bactericidal substances such as organic acids (lactic, acetic, butyric acid), $\mathrm{H}_{2} \mathrm{O}_{2}$ and bacteriocins, agglutination of pathogenic micro-organisms, adherence to the cellular surface of the mucosa and many others.

In addition, Bakre (2012) stated that the low pH induces the organic acid to become lipid soluble, which then diffuses through the cell membrane into the cytoplasm. Studies of several bacteriocins have indicated that they are nontoxic and non-immunogenic. Further, an investigation by Ekanem and Akintoye (1990) among mothers in a suburban community in Lagos to ascertain child feeding patterns during episodes of diarrhoea revealed that about $53 \%$ of the women increased the use of ogi-porridge during this crisis.

\section{Conclusion and Recommendation}

This study reveals that CSL has anti bacterial activities against the test organisms. It is therefore a beneficial and natural cure for diarrhoea. The CSL can therefore be preserved for subsequent use by concentration using modern technology like freeze drying.

\section{REFERENCES}

Adebolu TT, Olodun AO, Ihunweze BC (2007). Evaluation of ogi liquor from different grains for antibacterial activities against some commons diarrhoeal bacteria in South West Nigeria. Afr. J. Biotechnol. 6 (9):1140 - 1143

Aderiye BI, Laleye SA, Odeyemi AT (2007). Hypolipidemic effect of Lactobacillus and Streptococcus species from some Nigerian fermented foods. Res. J. Microb. 2 (6):538-544.

AOAC (1990). Official Methods of Analysis, Association of Official Analytical Chemist. Washington D.C

Ashebir M, Ashenafi M (1999). Assessment of the antibacterial activity of some food traditional medicinal plants on some food-borne pathogens. Ethiopia. J. Health Develop. 13(3):211-213.

Bakre S (2012): Unseen Forces: Microbes, Fermentation and Mankind. $53^{\text {rd }}$ Inaugural Lecture of the University of Lagos.

Bakre S, Olukoya OK, Smith S,Akpan A (1998). Comparison of Diaheagenic organismsin Ogi. J. Trop. Pediatr. 44:331-334.
Brink TB, Minekins M, Vander Vossen JM, Leer BJ (1994). Antimicrobial activity of Lactobacillus. J. Appl. Bacteriol. 77:1140-1148.

Caplice and Fitzgerald GF (1999). Food Fermentation: role of Microorganisms in food production and preservation. Int. J. Food Microbiol. 50:131-149.

Cheessbrough M (1994). Medical laboratory Manual for Tropical Countries. Vol.II. Microbiology. ELBS. Cambridge University Press. Great Britain. p. 479.

Ekanem EE, Akintoye CO (1990). Child feeding by Nigerian mothers during acute diarrhoeal illness. J. Royal Soc. Promot. Health 110 (5):164-165

George-Okafor UO and Anosike EE (2011). Fermented corn waste liquor as a potential source for probiotic lactic acid bacteria. Nig. J. Biotechnol. 22:17-22.

Lindgren SW, Dobrogosz WJ(1990).Antagonistic activities of lactic acid bacteria in food and feed fermentation. FEMS Microbial Rev. 87:149164.

Marteau P, Seksik P, Jian R. (2002). Probiotics and intestinal health effects: a clinical perspective. British J. Nutr. 8(1):S51-S57.

Marugg JD (1991). Bacteriocins, their role in developing natural products. Food Biotechnol. 5(3):305-312

Odunfa SA, Adeleye SJ (1985). Microbiological changes during the traditional fermentation of ogi-baba, a West African fermented gruel. J. Cereal Sci. 3:173-180.

Ogunbanwo ST, Sanni AI, Onilude AA (2003). Influence of Cultural conditions on the production of bacteriocin by Lactobacillus brevis Afr. J. Biotechnol. 2(7):179-184.

Olukoya DK, Ebigwei SI, Olasupo NA, Ogunjimi AA (1994). Production of DogiK:an Improved Ogi (Nigerian Fermented Weaning Food) with Potentials for Use in Diarrhoea Control. J. Trop. Pediatr. 40(2):108113.

Oyetayo VO, Osho B (2004). Assessment of probiotic properties of a strain of Lactobacillus plantarum isolated from fermenting corn slurry. J. Food Agric. Environ. 2 (1):132 - 134.

Prescott LM, Hurley PJ, Klein AD (2005). Microbiology. McGraw-Hill, Publisher, Singapore. $6^{\text {th }}$ edition, 1126.

Savadogo A, Outtara CA, Bassole IH, Traore SA (2006). Bacteriocins and lactic acid bacteria - a mini review. Afr. J. Biotechnol. 5(9):678683.

Vrese M, Marteau PR (2007). Effects of probiotics and prebiotics supplement on diarrhoeal. The Amer. Society Nutr. 137:803S-811S.

Welderman RJ (1998). Epidemiological determinants of spread of causal agents of diarrhoeal disease. Lancet 361:1761-1767. 